\title{
SHOULD A LICENSING MARKET REQUIRE LICENSING?
}

\author{
MARK A. LEMLEY* \\ I \\ INTRODUCTION
}

It is commonplace in modern copyright scholarship to decry the demise of the fair use doctrine. ${ }^{1}$ As copyright continues its apparently unstoppable expansion in scope, duration, and strength, ${ }^{2}$ fair use seems unable to rise to the challenge of preserving a vibrant space in which people are free to "tinker" with or recode copyrighted works. ${ }^{3}$

Part of the problem is procedural-fair use is a defense that the accused infringer must prove. ${ }^{4}$ Because fair use relies upon a vague, multi-factor test, it

Copyright (C) 2007 Mark A. Lemley. Anyone may make verbatim copies of this article for noncommercial purposes so long as the following notice is retained on all publicly distributed copies:

(C) 2007 Mark A. Lemley. Originally published in Symposium, Cultural Environmentalism @

10, 70 LAW \& CONTEMP. Probs. (James Boyle \& Lawrence Lessig, eds., Spring 2007).

Licensed under the Creative Commons Attribution-NonCommercial-NoDerivs License. To view a copy of this license, visit http://creativecommons.org/licenses/by-nc-nd/3.0/ or send a letter to Creative Commons, 543 Howard Street, 5th Floor, San Francisco, California, 94105, USA.

This article is also available at http:/law.duke.edu/journals/lcp.

* William H. Neukom Professor of Law, Stanford Law School; of counsel, Keker \& Van Nest LLP.

Thanks to Julie Cohen, Jim Gibson, Paul Goldstein, Rose Hagan, Larry Lessig, Doug Lichtman, David McGowan, David Nimmer, Tyler Ochoa, and Sara Stadler for comments on an earlier draft.

1. See, e.g., Wendy J. Gordon, Fair Use: Threat or Threatened?, 55 CASE W. RES. L. REV. 903 (2005); Michael J. Madison, Rewriting Fair Use and the Future of Copyright Reform, 23 CARDOZO ARTS. \& ENT. L.J. 391, 393 (2005) ("Both abstractly and concretely, however, fair use has been spectacularly unsuccessful as a substantive player in copyright theory and practice.").

2. I wrote about this expansion in Mark A. Lemley, Romantic Authorship and the Rhetoric of Property, 75 TEX. L. REV. 893 (1997), and that was before the passage of the Digital Millennium Copyright Act and the Sonny Bono Copyright Term Extension Act or the judicial creation of a right against inducement. See MGM v. Grokster, 545 U.S. 913 (2005). But see Paul Goldstein, Copyright's Commons, 29 COLUM. J.L. \& ARTS 1, 3 (2005) (denying that copyright has expanded greatly in recent years).

3. On the recoding of copyrighted works, see Rebecca Tushnet, Payment in Credit: Copyright Law and Subcultural Creativity, 70 LAW \& CONTEMP. PROBS. 135 (Spring 2007). I take for granted in this paper the desirability of allowing some such tinkering, and leave for elsewhere the defense of this basic goal.

4. Campbell v. Acuff-Rose Music, Inc., 510 U.S. 569 (1994). Glynn Lunney has criticized this conclusion as a misreading of the statutory language and of Sony, see Glynn S. Lunney, Jr., Fair Use and Market Failure: Sony Revisited, 82 B.U. L. REV. 975, 989 (2002), but given that the Supreme Court treats it as a defense it is likely to remain a defense. $C f$. Princeton Univ. Press v. Mich. Doc. Servs., 99 F.3d 1381 (6th Cir. 1996) (en banc) (placing the burden of proof on the plaintiff if the use is noncommercial and on the defendant if the use is commercial, in an effort to reconcile Campbell and Sony). 
is often impossible to know ex ante whether any particular use will qualify as fair. The result, as Larry Lessig has put it, is that fair use is reduced to nothing more than the right to hire a lawyer. ${ }^{5}$ Individuals, non-profits, and small companies may not be able to afford that lawyer. ${ }^{6}$ Even large studios and publishing houses that could afford to litigate fair use generally don't; they are generally willing to go to great lengths to find copyright owners and pay licensing fees, or require modification of the work, rather than test their rights in court.

But a significant substantive development in the last two decades has shrunk fair use as well: the willingness of the courts to find a use unfair, even though it did not cost the copyright owner a sale, because the copyright owner could have gotten a licensing payment from the accused infringer. ${ }^{8}$ The result has been that even highly transformative uses that do not substitute for sales by the copyright owner are found unfair, and control over those uses defaults to the copyright owner. ${ }^{9}$

The goal of this paper is not to challenge this restrictive view of fair use. Others have done that..$^{10}$ Rather, it is to suggest that in many circumstances fair use should separate the idea that the copyright owner should be compensated for a use from the idea that the copyright owner should be able to control that

5. Lawrence Lessig, Free Culture: How Big Media Uses Technology and the Law TO LOCK DOWN CULTURE AND CONTROL CREATIVITY 187 (2004). To be fair, whenever a legal rule is sufficiently uncertain it is susceptible of the same characterization; copyright owners may justifiably claim that many of the rights they have in the statute are similarly impractical to enforce. See R. Polk Wagner, The Perfect Storm: Intellectual Property and Public Values, 74 Fordham L. ReV. 423, 428 (2005). This fact may create a substantial practical freedom within which people can make uses that would likely be fair, though the searchability of private work in the online era and the fact that commercial publishers will not take similar risks both limit the scope of that practical freedom. I am indebted to Paul Goldstein for this point.

6. The American Intellectual Property Law Association Report of the Economic Survey of its members reports mean litigation costs in copyright cases at roughly $\$ 700,000$ per side in medium-sized cases ( $\$ 1$ million to $\$ 25$ million at stake) and \$1.6 million in high-stakes copyright cases (more than $\$ 25$ million at stake). AIPLA, REPORT OF THE ECONOMIC SURVEY 24 (2005).

7. For examples, see LESSIG, supra note 5, at 95-99, 187-88. In part this may be because they have no vested interest in strengthening fair use rights, which will be used against them at least as often as it benefits them. Or it may be because their errors-and-omissions insurers are risk-averse.

A striking counterexample is Houghton-Mifflin v. Sun Trust Bank, 268 F.3d 1257 (11th Cir. 2001), in which a publisher was willing to challenge the copyright owners of Margaret Mitchell's Gone With the Wind.

8. See, e.g., Am. Geophysical Union v. Texaco, Inc., 60 F.3d 913 (2d Cir. 1994).

9. It may also reinforce the procedural problems, since no lawyer can advise a client as to whether a use is fair without investigating whether a market for licensing uses of the client's ilk exists or could reasonably be expected to develop.

10. See, e.g., Pierre N. Leval, Toward a Fair Use Standard, 103 HARV. L. REV. 1105, 1124 (1990) ("By definition, every fair use involves some loss of royalty revenue because the secondary user has not paid royalties."); William W. Fisher III, Reconstructing the Fair Use Doctrine, 101 HARV. L. REV. 1659, 1671 (1988); Sara K. Stadler, Forging a Truly Utilitarian Copyright, 91 IOwA L. REV. 609 (2006); Christina Bohannon, Reclaiming Copyright, 23 CARDOZO ARTS \& ENT. L.J. 567, 597-98 (2006); Matthew Sag, God in the Machine: A New Structural Analysis of Copyright's Fair Use Doctrine, 11 Mich. TeleComm. \& TeCH. L. ReV. 381, 393-94 (2005); Lydia Pallas Loren, Redefining the Market Failure Approach to Fair Use in an Era of Copyright Permission Systems, 5 J. INTELL. PROP. L. 1, 38-39 (1997). 
use. The licensing-market cases provide a perfect vehicle for dividing those rights. If the only reason a use is considered unfair is because the copyright owner could have gotten paid to permit that use, that argument may-or may not-justify compensating the copyright owner for that "loss," but it does not justify giving the copyright owner control over the defendant's use.

Part II explains the development of the licensing-market rationale, critiques of that rationale, and its significance for the scope of the fair use doctrine. In Part III I take the licensing-market rationale as a given, and argue that even if copyright owners can defeat a fair use claim on this basis, they should not be entitled to an injunction. Rather, courts should use their discretion to deny injunctive relief when the copyright owner's only legitimate interest is in compensation rather than control. Finally, Part IV uses this argument to begin a discussion of what it means to deny injunctive relief in copyright. The subset of copyright remedies that are designed to deter infringement needs to be modified in circumstances in which a court finds that compensation but not control is the appropriate remedy. I consider some possible changes to the statute designed to achieve that sensible result.

II

\section{LICENSING MARKETS AND FAIR USE}

Resolving claims of fair use has long required a case-specific, multifactor balancing test, and indeed that test is now enshrined in the Copyright Act. ${ }^{11}$ Of the four factors-the purpose of the defendant's use, the nature of the copyrighted work, the amount taken, and the market effect on the copyright owner-the market-effect factor has generally been considered the most important. ${ }^{12}$ This likely reflects a logical connection between copyright law and market injury. Since the purpose of copyright is to encourage new creation by ensuring that creators get paid, copyright law's logical concern should be primarily, if not exclusively, with infringing uses that deprive creators of revenue they could otherwise have expected to receive. On this view, fair use should encompass acts that are unlikely to result in market harm-private uses by consumers, uses (like criticism or parody) so transformative that they are unlikely to substitute for the copyrighted work, or other acts that do not interfere with the market for the copyrighted work. And indeed much of the economic literature on fair use has just such a focus, defining fair uses as ones that an objectively reasonable copyright owner would agree to and which do

11. 17 U.S.C. $\$ 107$ (2000).

12. See, e.g., Harper \& Row, Publishers, Inc. v. Nation Enters., 471 U.S. 539, 566 (1985) (calling the fourth factor "undoubtedly the single most important element of fair use."). But see David Nimmer, "Fairest of Them All" and Other Fairy Tales of Fair Use, 66 LAW \& CONTEMP. PROBS. 263, 280 (Winter/Spring 2003) (finding that the market-effect factor lined up with a fair use finding only fifty percent of the time, but using a narrower definition of market effect than the courts do). 
not interfere with the copyright owner's market. ${ }^{13}$ Transformativeness and the extent of the taking matter for fair use on this analysis, ${ }^{14}$ but only as a secondary indicator of what the doctrine really cares about: whether the use substitutes for the copyrighted work and so is likely to cost the copyright owner a sale. ${ }^{15}$

In recent decades the scope of copyright infringement has expanded dramatically, to the point that a wide variety of private uses-sharing music with friends ${ }^{16}$ writing notes in your law school casebook,${ }^{17}$ framing a picture ${ }^{18}$ maybe even singing in a hotel room shower ${ }^{19}$ - now arguably fall within the

13. The classic cite for this proposition is Wendy J. Gordon, Fair Use and Market Failure: A Structural and Economic Analysis of the Betamax Case and Its Predecessors, 82 Colum. L. REV. 1600 (1982). Glynn Lunney has critiqued this approach as overly narrow, see Lunney, supra note 4; Gordon has argued that her work has been read too narrowly and that she understands fair use to be based upon more than transactions costs, Wendy J. Gordon, Market Failure and Intellectual Property: A Response to Professor Lunney, 82 B.U. L. REV. 1031 (2002). Cf. Robert Merges, Are You Making Fun of Me? Notes on Market Failure and the Parody Defense in Copyright, 21 AIPLA Q.J. 305 (1993); Richard Posner, When Is Parody Fair Use?, 21 J. LegAL STUD. 79 (1992).

14. See, e.g., Campbell v. Acuff-Rose Music, Inc., 510 U.S. 569, 579 (1994) ("The central purpose of this [fair use] investigation is to see, in Justice Story's words, whether the new work merely 'supersede[s] the objects' of the original creation, or instead adds something new, with a further purpose or different character, altering the first with new expression, meaning, or message; it asks, in other words, whether and to what extent the new work is 'transformative."'); Am. Geophysical Union v. Texaco, Inc., 60 F.3d 913, 920 (2d Cir. 1994) (emphasizing the role of transformative use in the first factor, and questioning whether nontransformative copies should ever qualify as fair use). For the origins of the idea of transformative versus superseding uses, see Folsom v. Marsh, 9 F. Cas. 342 (C.C.D. Mass. 1841); Pierre N. Leval, Toward a Fair Use Standard, 103 HARV. L. REV. 1105 (1990); LEON E. SELTZER, EXEMPTIONS AND FAIR USE IN COPYRIGHT 24 (1978).

15. See William M. Landes \& Richard A. Posner, The Economic Structure of INTELLECTUAL PROPERTY LAW 153-57 (2003) (making this argument as a justification for the transformative-use doctrine).

There is another, smaller class of cases that does not fit easily into this analysis-those cases in which the public-interest nature of the use predominates. See, e.g., Time, Inc. v. Bernard Geis Assocs., 293 F. Supp. 130 (S.D.N.Y. 1968) (finding a scholar's surreptitious photography of the Zapruder film of the Kennedy assassination to be fair use, largely because of the extreme newsworthiness of the copyrighted work). Alan Cranston's full translation of Mein Kampf to expose its anti-Semitism surely ought to fit into this category, though in that case the courts actually found copyright infringement. See Houghton Mifflin Co. v. Noram Publ'g Co., 28 F. Supp. 676 (S.D.N.Y. 1939); see also Houghton Mifflin Co. v. Stackpole Sons, Inc., 104 F.2d 306 (2d Cir. 1939). Those cases are discussed further infra note 48 and accompanying text. See also Neil Weinstock Netanel, Locating Copyright Within the First Amendment Skein, 54 STAN. L. REV. 1, 15-16 (2001) (citing other examples).

16. The copying of music using music-specific media is protected under 17 U.S.C. $\S 1008$. But similar copying done via computer-as almost all music file sharing is these days-is not protected by the statute. See A\&M Records, Inc. v. Napster, Inc., 239 F.3d 1004, 1024-25 (9th Cir. 2001).

17. Modifications to an existing copy of a copyrighted work that as a whole add copyrightable expression are infringing derivative works. See 17 U.S.C. $\$ 106(2)$. In some circuits, the modifications need not even rise to that level. See Mirage Editions, Inc. v. Albuquerque A.R.T. Co., 856 F.2d 1341 (9th Cir. 1988); Midway Mfg. Co. v. Arctic Int'l, 704 F.2d 1009, 1014 (7th Cir. 1983) (speeding up the play of a video game creates a derivative work). But see Lee v. A.R.T. Co., 125 F.3d 580 (7th Cir. 1997); Gracen v. Bradford Exch., 698 F.2d 300 (7th Cir. 1983) (requiring new copyrightable expression to create a derivative work).

18. See DAVID NimMER, NimMER ON COPYRIGHT $\S 3.0$ (noting this implication of Mirage). But cf. Munoz v. Albuquerque A.R.T. Co., 829 F. Supp. 309 (D. Alaska 1993) (attempting to distinguish framing a picture from gluing the picture to a tile on the ground that the former is not a permanent change), aff'd, 38 F.3d 1218 (9th Cir. 1994) (unpub.).

19. Public performance of a musical work is copyright infringement. 17 U.S.C. $\S 106(4)$. A performance is "public" if it occurs at a place open to the public. 17 U.S.C. $§ 101$. The Third Circuit 
scope of the Act. To be sure, some of this expansion results from technological changes that have conflated the public and private spheres. ${ }^{20}$ But much of it results from changes to the Copyright Act and broad interpretations of that Act by courts, ${ }^{21}$ particularly the development of the derivative works right. ${ }^{22}$

If the purpose of fair use is to align the copyright law with creative incentives by distinguishing between uses that interfere with those incentives and uses that do not, it would seem logical to expect that fair use, too, would have expanded in recent years as copyright encroached more and more on private or transformative uses that did not affect those incentives. But that is not what has happened. Instead, the role of fair use appears to be shrinking, not expanding, with the result that lots of uses that do not interfere with a copyright owner's traditional markets are still likely to be deemed acts of infringement.

The reason for this seemingly odd change in fair use doctrine is a new approach to the analysis of market effect. Beginning in the $1990 \mathrm{~s}^{23}$ and most notably in American Geophysical Union v. Texaco, ${ }^{24}$ courts began to count as market harm not just actual lost sales of the copyrighted work or plausible derivative works, but also the loss of money they supposed users would pay to license the right to use the copyrighted work. In Texaco, the plaintiffs were a consortium of academic journal publishers who sued Texaco because its scientists regularly made photocopies of journal articles for use in their research. Texaco had bought subscriptions to the journals, and indeed paid an institutional subscription fee that was considerably higher than the fee the plaintiffs charged an individual for the same copy. ${ }^{25}$ Nonetheless, the plaintiffs argued that Texaco's use was unfair because the copies it made substituted for

has held that a place is open to the public if it is for rent, even if it is occupied by only one person at a time. Columbia Pictures Indus. v. Aveco, Inc., 800 F.2d 59, 63 (3d Cir. 1986) ("The Copyright Act speaks of performances at a place open to the public. It does not require that the public place be actually crowded with people. A telephone booth, a taxi cab, and even a pay toilet are commonly regarded as 'open to the public,' even though they are usually occupied only by one party at a time."); Columbia Pictures Indus. v. Redd Horne, 749 F.2d 154, 158 (3d Cir. 1984). But see Columbia Pictures Indus. v. Prof'l Real Estate Investors, 866 F.2d 278 (9th Cir. 1989) (reaching the opposite conclusion). If a hotel room is a public place, singing there without authorization is infringement.

20. See, e.g., Mark A. Lemley \& R. Anthony Reese, Reducing Digital Copyright Infringement Without Restricting Innovation, 56 STAN. L. REV. 1345 (2004) (making this point about digital music).

21. To take just one example, the definition of an infringing copy, which once required substantial similarity, if not identity, has been eroded to the point where some courts have held that any literal similarity, no matter how small, is a copy. See, e.g., Bridgeport Music v. Dimension Films, 401 F.3d 647 (6th Cir. 2004) (finding no de minimus exception to infringement in the special context of copying of phonorecords under section 114).

22. 17 U.S.C. § 106(2).

23. Frank Pasquale traces the development of this idea to Justice Blackmun's dissent in Sony, which argued that "the infringer must demonstrate that he had not impaired the copyright owner's ability to demand compensation from ... any group who would otherwise be willing to pay." Universal Studios v. Sony Corp. of Am., 464 U.S. 417, 485 (1984) (Blackmun, J., dissenting). Pasquale describes Blackmun's idea as coming "out of thin air, grounded neither in the relevant statutory language nor in any convincing economic or moral analysis ...." Frank Pasquale, Breaking the Vicious Circularity: Sony's Contribution to the Fair Use Doctrine, 55 CASE W. RES. L. REV. 777, 778 (2005).

24. 60 F.3d 913 (2d Cir. 1994).

25. Am. Geophysical Union v. Texaco, Inc., 802 F. Supp. 1, 7 (S.D.N.Y. 1992). 
the copyrighted work; Texaco, they alleged, would have bought more copies of the same journals to route to its scientists if they could not make photocopies. This argument fits squarely within the traditional rationale for rejecting a fair use defense. But the plaintiffs couldn't prove it. ${ }^{26}$ Instead, they prevailed on a theory that even though they couldn't show lost sales of the journal itself, they had lost potential licensing revenue, because Texaco might have been willing to pay a royalty for the right to make a copy. ${ }^{27}$ Other cases have rejected fair use claims on a similar theory of lost licensing revenue. ${ }^{28}$

The "lost licensing revenue" theory is ultimately circular. ${ }^{29}$ Whether a use is fair depends on whether the copyright owner loses anything from the use, but under Texaco, whether the copyright owner loses anything from the use depends on whether the use is deemed fair; only if it is not a fair use would there be licensing revenue to lose. The result is to unmoor fair use from the traditional rationale of market loss and to potentially make any use for which the user could afford to pay into a use for which they must pay. To be sure, the Second Circuit and other courts have sought to avoid the circularity problem by limiting claims for lost licensing revenue to "traditional, reasonable, or likely to be developed" licensing markets, ${ }^{30}$ but this effort is likely to be unavailing. Once courts announce that a copyright owner can stop uses of their work merely by offering to charge for those uses, it is reasonable to expect that copyright owners will strive to develop just such a licensing market. ${ }^{31}$ And indeed they

26. 60 F.3d at 914 (majority); id. at 932 (dissent).

27. Id. at 30. Whether Texaco would in fact have been willing to make such a payment to the Copyright Clearance Center (CCC) is unclear. The CCC's fees are quite high, often $\$ 1.00$ per page or above, and it may well have been cheaper to buy extra copies of the journals. The CCC also offers a blanket fee for access to all of its journals, though it uses econometric measures to calculate the fee so that it approximates the per-copy cost-that is, it is not a discount. STANLEY M. BESEN \& SHEILA Nataraj Kirby, Compensating Creators of InTEllectual Property: Collectives that COLLECT (1989). If Texaco was not willing to make that extra payment, it is not clear why it would have been willing to pay such a high license fee. This is particularly true because the likely alternative to photocopying in the Texaco case was probably for Texaco's scientists to take notes about the facts and unprotectable ideas in the articles that interested them rather than to buy a new copy of every journal they read. In any event, the court did not consider Texaco's willingness to pay in rendering its decision.

28. See, e.g., Princeton Univ. Press v. Mich. Doc. Servs., 99 F.3d 1381 (6th Cir. 1996) (en banc); Basic Books v. Kinko's Graphics Corp., 758 F. Supp. 1522 (S.D.N.Y. 1991).

29. The dissent pointed out this circularity, Am. Geophysical, 60 F.3d at 937 (Jacobs, J., dissenting), and others have criticized the majority opinion for it as well. See supra note 25 (citing commentators).

30. Am. Geophysical, 60 F.3d at 930; Field v. Google Inc., 412 F. Supp. 2d 1106, 1122 (D. Nev. 2005) (rejecting a claim of injury to a market for licensing caching of Internet works because "there is no evidence before the Court of any market for licensing search engines the right to allow access to Web pages through 'Cached' links").

The Second Circuit has recently imposed a potentially far more significant limitation on Texaco. In Bill Graham Archives v. Dorling Kindersley Ltd., 448 F.3d 605, slip op. at 20-21 (2d Cir. May 9, 2006), the Second Circuit seemed to hold that Texaco did not apply to works that were sufficiently transformative. If that is true, and those uses are held fair notwithstanding the potential loss of licensing revenue, the problem addressed in this paper will be significantly abated.

31. The problem may be worse than that. As Jim Gibson observes, if potential copyright defendants are risk-averse, they may take licenses even when they would have had a good claim of fair use. And if they do so, the licensing-market theory will over time expand copyright to cover their conduct, even though they were unreasonable at the time in seeking a license rather than relying on fair 
have done so. Not only has the market for photocopy permissions skyrocketed ${ }^{32}$ but copyright owners are charging for rights to home viewing of television programs,${ }^{33}$ rap-music samples ${ }^{34}$ and even the right to parody their works. ${ }^{35}$ One can similarly imagine a copyright owner making claims of lost revenue from being unable to license fan fiction, ${ }^{36}$ satire, and even criticism. ${ }^{37}$ Indeed, in one notable case they succeeded in stopping what would otherwise have been a fair use by creating a market for licensing after suing to stop the use..$^{38}$ The result has been to contract the doctrine of fair use to a few protected categories, with the baseline assumption being that any use requires permission and a licensing fee. ${ }^{39}$

III

\section{SEPARATING COMPENSATION AND CONTROL IN LICENSING MARKETS}

Fair use is an all-or-nothing doctrine: when it applies, the copyright owner gets neither an injunction nor damages; when it does not apply, they are entitled

use. James Gibson, Risk Aversion and Rights Accretion in Intellectual Property Law, 116 YALE L.J. 882, 887 (2007). For earlier elaboration of this problem, see Ann Bartow, Educational Fair Use in Copyright: Reclaiming the Right to Photocopy Freely, 60 U. PITT. L. REV. 149 (1998); Lydia Pallas Loren, Redefining the Market Failure Approach to Fair Use in an Era of Copyright Permission Systems, 5 J. INTELL. PROP. L. 1 (1997). This is a particularly significant problem given the documented tendency of many publishers to require licensing even of uses that seem clearly fair. See LESSIG, supra note 5 (giving examples).

32. The Copyright Clearance Center, in its infancy when American Geophysical was decided, has grown to manage copyrights for over 1.75 million works and counts most of the world's largest companies as buyers. Copyright Clearance Center Corporate Overview, http://www.copyright.com/ccc/do/viewPage?pageCode=au1 (last visited Sept. 24, 2006). Its revenues in 2005 were more than five times what they were in 1994. COPYRIGHT CLEARANCE CENTER 2005 ANNUAL REPORT, http://www.copyright.com/media/pdfs/AR_CCC_05_Spreads.pdf (last visited Sept. 24, 2006).

33. See Netflix News \& Info., http://www.hackingnetflix.com/2005/10/apple_licenses_html (last visited Sept. 24, 2006) (discussing the iPod TV show licenses).

34. See Olufunmilayo B. Arewa, From J.C. Bach to Hip Hop: Musical Borrowing, Copyright and Cultural Context, 84 N.C. L. REV. 547, 634-38 (2006); Carlos Ruiz de la Torre, Digital Music Sampling \& Copyright Law, 7 VAND. J. ENT. L. \& PRAC. 401, 402 (2005); Carlos Ruiz de la Torre, Digital Music Sampling and Copyright Law: Can the Interests of Copyright Owners and Sampling Artists Be Reconciled?, 8 VAND. J. ENT. L. \& PRAC. 503 (2006) (discussing the market for licensing samples in rap songs).

35. Weird Al Yankovic, who writes spoofs of popular music, pays to license the rights to the songs he parodies. He describes rights clearance as the hardest part of his job. Gerry Galipault, 'Weird Al' Has a License to Shill, Sept. 5, 1999, http://www.pauseandplay.com/weirdal.htm. He may do so, however, for reasons related to social norms in Hollywood rather than legal compulsion.

36. On fan fiction norms and how they interact with copyright, see Tushnet, supra note 3.

37. Cf. Ty, Inc. v. Publ'ns Int'l, 292 F.3d 512 (7th Cir. 2002) (discussing the possibility of a license for criticism).

38. Perfect 10 v. Google Inc., 416 F. Supp. $2 d 828$ (C.D. Cal. 2006) (rejecting a fair use claim for a search engine's use of thumbnail images because, after that use began, the plaintiff began selling thumbnail images for viewing on cell phones).

39. See, e.g., Sara K. Stadler, The Incentives Trap, or Why Copyright Is Like a Corkscrew 7 (Emory Law and Economics Research Paper No. 06-01, 2006) ("[B]y making it easy to take a license in those markets, copyright owners increasingly have redefined an 'unfair use' as an unlicensed one."). 
to both. ${ }^{40}$ Rejecting a claim of fair use thus gives the copyright owner both the right to compensation for the defendant's use and the right to prevent or control the circumstances of that use. And courts have given teeth to that right, not only finding infringement and awarding damages but also granting injunctions against works that did not pay a licensing fee, even if the copyrighted work was only a small part of the enjoined work. ${ }^{41}$

In fact, however, there are many circumstances in which the issues of copyright-owner compensation and control should logically be separated..$^{42}$ For example, consider the class of cases in which the defendant's use is transformative. In many of those cases-those that involve a market failure of some sort-even if the fair use claim is rejected, society will be best served by a rule that allows compensation for the copyright owner but denies them control over the defendant's work. Giving the copyright owner control puts the dissemination of the defendant's original expression at the mercy of the copyright owner, and copyright owners may be particularly bad stewards of other people's takes on their works. This may be true not only when that additional expression is unflattering ${ }^{43}$ but also when it is simply undervalued ${ }^{44}$ or when for a host of reasons the parties cannot come to terms. ${ }^{45}$ This argument applies with particular force if the new transformative content is not separable from the copyrighted material, so that an injunction will necessarily ban the distribution not just of infringing material but also of original, noninfringing

40. See Alex Kozinski \& Christopher Newman, What's So Fair About Fair Use?, 46 J. Copyright SoC'Y 513 (1999) (making this point and arguing that copyright owners should be entitled only to damages).

41. See, e.g., Woods v. Universal City Studios, 920 F. Supp. 62 (S.D.N.Y. 1996) (enjoining distribution of the film 12 Monkeys during its initial release because the movie featured a copyrighted chair in three scenes); Jeff Leeds, Judge Freezes Notorious B.I.G. Album, N.Y. TIMES, Mar. 21, 2006, at B2 (noting a court decision enjoining sales of multi-platinum rap album because it contained unlicensed samples from Funkadelic).

42. I am not the first to suggest this separation of compensation and control. See Wendy J. Gordon, A Property Right in Self-Expression: Equality and Individualism in the Natural Law of Intellectual Property, 102 YAlE L.J. 1533, 1573-76 (1993); Olufunmilayo B. Arewa, Copyright on Catfish Row: Control and Compensation in Porgy and Bess 93 (working paper 2005) ("This connection between control and compensation, however, is neither inevitable nor necessary. It would be possible, for example, to structure an intellectual property system that offered a compensation mechanism without entitling the holder to control rights in their current form."). Arewa goes on to suggest giving the heirs of copyright owners compensation rights but only limited control rights, $i d$. at 76 , a laudable proposal but one outside the scope of this article. See also Tehranian, infra note 83, at 1241-42 (suggesting a liability rule for transformative uses with profit-sharing rather than damages calculation).

43. See Merges, supra note 13; Posner, supra note 13 (discussing the problems with a market for licensing parodies). Although it is true that some parodists do manage to obtain licenses for their works, see supra note 35 (discussing Weird Al Yankovic), it is not a good idea to give copyright owners such control. Many will not license the right to make fun of them, while others may license relatively tame parodies but not more biting ones.

44. For example, Roy Orbison's music company was unwilling to license the rights to remake "Pretty Woman" to 2 Live Crew at any price. See Campbell v. Acuff-Rose Music, Inc., 510 U.S. 569 (1994). The record is silent on why that is, but one plausible explanation is that it did not see the value in rap music.

45. See Mark A. Lemley, The Economics of Improvement in Intellectual Property Law, 75 TEX. L. REV. 989, 1048-72 (1997) (discussing the myriad reasons efficient copyright licensing might not occur). 
content. ${ }^{46}$ Even if one were to conclude that the copyright owner deserves compensation as a result of a defendant's derivative use, that doesn't mean the defendant's additional expression is not also valuable.

A second example involves those rare cases in which the perceived public benefit in disseminating a work is sufficient to overwhelm market factors. These are often cases in which the copyright owner's interest is in suppressing some fact of social significance. Alan Cranston translated and published the full text of Mein Kampf in the 1930s, when Hitler was selling an authorized translation that toned down his anti-Semitism. Cranston's use was not terribly transformative-his goal was an accurate translation-and it certainly cut into the market for Hitler's sales. But the public interest in learning about what Hitler actually thought and planned provided an important reason to permit Cranston's use to go forward. Courts will sometimes resolve these public interest cases by finding fair use, ${ }^{47}$ but not always. ${ }^{48}$ Sometimes they permit copyright owners to retain control even over important historical documents. ${ }^{49}$ When that happens, it is at most compensation, not control, that the copyright owner deserves.

Finally, compensation without control may be the appropriate remedy when the production of a particular type of work requires clearances of so many rights, or when rights owners are so hard to find, that doing so would be uneconomic. The law provides compulsory licenses in a number of situations like this, ${ }^{50}$ and private collective licenses have developed in others. ${ }^{51}$ Others have proposed compulsory licenses for clearing of peer-to-peer file sharing ${ }^{52}$ song samples, ${ }^{53}$ and orphan works. ${ }^{54}$

46. For a detailed discussion of this problem and how it affects the choice between property and liability rules, see Mark A. Lemley \& Philip J. Weiser, Should Property or Liability Rules Govern Information?, 85 TEX. L. REV. 783 (2007). Our basic point there is that property rules can facilitate holdup where the scope of the property right cannot be well tailored to preclude only infringement, but of necessity ends up banning noninfringing material as well. That is likely to happen when a court enjoins a transformative use of a copyrighted work.

47. See, e.g., Time, Inc. v. Bernard Geis Assocs., 293 F. Supp. 130 (S.D.N.Y. 1968).

48. Indeed, Cranston himself was held to violate Hitler's copyright. See Houghton Mifflin Co. v. Noram Publ'g Co., 28 F. Supp. 676 (S.D.N.Y. 1939).

49. See, e.g., Los Angeles News Service v. Tullo, 24 U.S.P.Q.2d 1026 (9th Cir. 1992) (videotapes of news events are copyrightable); Los Angeles News Serv. v. KCAL-TV, 108 F.3d 1119 (9th Cir. 1997) (television station could not broadcast videotape of the Reginald Denny beating without permission from the copyright owner; the court relied on the existence of a licensing market for the tape); David Nimmer, Copyright in the Dead Sea Scrolls: Authorship and Originality, 38 Hous. L. ReV. 1 (2001) (discussing Israeli Supreme Court decision upholding copyright over the Dead Sea Scrolls in those who had been reconstructing and translating them).

50. See, e.g., 17 U.S.C. $\S \S 111,114,115,118,119$ (2000).

51. See BMI v. CBS, Inc., 441 U.S. 1 (1979) (discussing private collective licenses for public performances of musical compositions).

52. William W. Fisher III, Promises to Keep: Technology, LaW and the Future of ENTERTAINMENT 199-258 (2004); Neil Weinstock Netanel, Impose a Noncommercial Use Levy to Allow Free Peer-to-Peer File Sharing, 17 HARV. J. L. \& TECH. 1 (2003).

53. Arewa, supra note 34, at 638-41. 
Sometimes-though not often-our instincts run in the opposite direction..$^{55}$ Copyright owners occasionally make claims that invoke an interest in control but not compensation. The easiest such example is attribution as the author of a work. There is no express attribution right in the Copyright Act, except in the case of some works of visual art. ${ }^{56}$ Further, it seems unlikely that trademark law can continue to play its traditional role in protecting an author's attribution interest. ${ }^{57}$ But our instinctive reaction is that plagiarism is a problem whether or not the act of copying interferes with the market for the work. In this case, the copyright owner's valid claim may not be for compensation, but for a certain measure of control: the ability to insist that she be identified as the author of the work. ${ }^{58}$ Even more clearly in the control category is an artist's right under VARA to protect the integrity of her work against mutilation..$^{59}$ If we truly think of these as moral rather than economic rights, the right remedy is not to compensate the copyright owner for their loss but to ensure that they retain some control over the use of their work. ${ }^{60}$

Judge Kozinski has suggested that copyright should provide compensation but no control as a general rule, eliminating both the fair use doctrine and a copyright owner's ability to obtain injunctive relief. ${ }^{61}$ I would not go that far. There are circumstances such as parody and criticism in which we should entirely excuse the user of a copyrighted work, because society benefits from

54. H.R. 5439, §514(b)(1)(A), 109th Cong. (2d Sess. 2006). See also United StATES COPYRIGHT OFFICE, REPORT ON ORPHAN WORKS (2006), available at http://www.copyright.gov/orphan/orphanreport-full.pdf.

55. For an argument for a much broader right to control the integrity of copyrighted works and the way the audience experiences them, see Justin Hughes, "Recoding" Intellectual Property and Overlooked Audience Interests, 77 TEX. L. REV. 923 (1999). But see Tushnet, supra note 3, at 157 (discussing the positive social value of such recoding).

56. 17 U.S.C. $\S 106$ A (2000).

57. In Dastar Corp. v. Twentieth Century Fox Film Corp., 539 U.S. 23, 37 (2003), the Supreme Court held that trademark and unfair competition law could not prevent misattribution of a work because the interests of those laws concerned only the source of the particular copy rather than the originator of the work. For cogent criticism of Dastar, see Laura A. Heymann, The Birth of the Authornym: Authorship, Pseudonymity, and Trademark Law, 80 NOTRE DAME L. REV. 1377 (2005); Greg Lastowka, The Trademark Function of Authorship, 85 B.U. L. REV. 1171 (2005); Jane C. Ginsburg, The Author's Name as a Trademark: A Perverse Perspective on the Moral Right of 'Paternity' (Columbia Law Sch. Pub. Law \& Legal Theory Working Paper Group, Paper No. 05-91, 2005), available at http://ssrn.com/abstract $=724343$. But see Jonathan Band \& Matt Schruers, Dastar, Attribution, and Plagiarism, 33 AIPLA Q.J. 1, 2 (2005) (defending the decision on both legal and policy grounds); David Nimmer, The Moral Imperative Against Academic Plagiarism (Without a Moral Right Against Reverse Passing Off), 54 DePAul L. ReV. 1 (2004).

58. At least one court has awarded injunctive relief but no damages for copyright infringement. Rubin v. Brooks/Cole Publ'g Co., 836 F. Supp. 909, 922 (D. Mass. 1993).

59. 17 U.S.C. $\S 106 \mathrm{~A}(\mathrm{a})(3)$.

60. Cf. Mark A. Lemley, Rights of Attribution and Integrity in Online Communications, $1995 \mathrm{~J}$. ONLINE L. art. 2 (May 1995), http://www.wm.edu/law/publications/jol/95_96/lemley.html.

61. Kozinski \& Newman, supra note 40. See also Jed Rubenfeld, The Freedom of Imagination: Copyright's Constitutionality, 112 YALE L.J. 1 (2002) (arguing for only damages in all derivative works cases). 
the repurposing of works in these ways. ${ }^{62}$ There are also circumstances (such as counterfeiting) in which ex post compensation may be insufficient to deter conduct that causes harm and has no redeeming social value. Injunctions may also sometimes be appropriate against transformative uses, though the case against injunctive relief is certainly stronger with such uses. There will be many circumstances in which even a derivative market should be supported by a property rule, because the derivative market competes directly with the original, so that compelling licensing would undermine the incentives associated with exclusivity. ${ }^{63}$

Licensing-market cases are one circumstance in which it seems to make sense to provide compensation but no control. The strongest argument for property over liability rules is the difficulty courts can have in measuring and assessing damages. Property rules are desirable, on this view, because private parties are more likely than courts or regulators to get the price right. ${ }^{64} \mathrm{But}$ if the primary reason a copyright owner prevailed over a fair use defense is because it claimed lost revenue from an established licensing market, the nature of its injury seems easily measurable and compensable in damages. The injury is the licensing fee the defendant would have paid. To give copyright owners not only the right to get paid for past uses but the right to forbid future uses suggests that they should somehow be entitled to prevent a paying defendant from making a use that by hypothesis is illegal only if the defendant isn't paying. Copyright owners should not be able to use a licensing-market claim as a front for what is really an interest in forbidding the use and foregoing licensing revenue.$^{65}$ And since it is a simple exercise for a court to assess damages in such a case, a liability rule seems to be a logical alternative.

Applying the "compensation but no control" rule might make some sense in the Texaco class of cases, and indeed the Texaco court itself suggested that injunctive relief might not be appropriate in that case. ${ }^{66}$ But those are not the important cases. It is in cases in which the defendant's use is transformative that separating compensation and control would have its most significant

62. On the importance of parody and satire in Western literature and culture, see Tyler T. Ochoa, Dr. Seuss, the Juice, and Fair Use: How the Grinch Silenced a Parody, 45 J. COPR. SOC'Y USA 546 (1998).

63. Cf. Neil Weinstock Netanel, Copyright and a Democratic Civil Society, 106 YALE L.J. 283, 378 (1996) ("[I]n many instances [though not all] the elimination of the exclusive derivative right would undermine the incentive that copyright provides for the creation of the original work.").

64. James E. Krier \& Stewart J. Schwab, Property Rules and Liability Rules: The Cathedral in Another Light, 70 N.Y.U. L. REV. 440 (1995); Richard A. Epstein, A Clear View of The Cathedral: The Dominance of Property Rules, 106 YALE L.J. 2091, 2093 (1997).

65. Sometimes such claims are really efforts to obtain moral rights that the law does not grant copyright owners. Those moral rights may be good or bad, but the law should grant or not grant them on their merits, and not permit copyright owners to obtain moral rights through the back door by claiming harm to an illusory licensing market.

66. Am. Geophysical Union v. Texaco, Inc., 60 F.3d 913, 932 n.19 (2d Cir. 1994) ("[W]e note that the context of this dispute appears to make ill-advised an injunction.... If the dispute is not now settled, this appears to be an appropriate case for exploration of the possibility of a court-imposed compulsory license."). 
benefits. In those cases, the defendant has contributed original creative expression. If the copyright owner is willing to license that expression, the Texaco rationale suggests that the defendant will have to pay. But if the copyright owner is not, in fact, willing to license-if, having been given control, the copyright holder will seek to stop the defendant's use altogether-the rationale for declaring the use unfair in the first place collapses. Had it been known all along that the copyright owner was not willing to accept licensing revenue, courts would have declared the use fair rather than enjoining it. A compensation-without-control rule will make sure that courts do not wrongly enjoin creative expression. ${ }^{67}$ In transformative-use cases, in other words, it's not just that copyright owners will be fully compensated by a liability rule; a liability rule is superior to a property rule because it avoids the problem of suppressing uncopyrighted speech. ${ }^{6}$

In short, even if one takes as given the idea that lost licensing revenue is a real rather than hypothetical harm to copyright owners, it is not clear that we should simply give the plaintiffs the full panoply of copyright remedies. Part IV considers how to implement this idea.

\section{IV}

\section{TOWARD A COMPENSATORY MODEL OF COPYRIGHT REMEDIES}

\section{A. Supracompensatory Remedies in Copyright Law}

The idea of the last section is simple enough-if the only reason the copyright owner is entitled to relief against a transformative use is because of its claim that it would have licensed the defendant for a particular fee, the copyright owner's remedy ought to be limited to that fee. The copyright owner should not be entitled to stop the use; had it asserted in the liability phase that it wanted to prevent the use rather than license it, the court would have deemed the use fair and the copyright owner would have gotten nothing.

Implementing this idea turns out to be surprisingly difficult in the context of the current copyright statute. The copyright statute makes injunctive relief discretionary rather than mandatory, ${ }^{69}$ and the Supreme Court has said on multiple occasions that injunctive relief may not be appropriate even after a

67. On the First Amendment problems with copyright injunctions, see, e.g., Mark A. Lemley \& Eugene Volokh, Freedom of Speech and Injunctions in Intellectual Property Cases, 48 DUKE L.J. 147 (1998).

68. Phil Weiser and I have generalized this point in a companion paper. See Lemley \& Weiser, supra note 46.

69. 17 U.S.C. $\S 502(a)$ (2000) ("Any court ... may ... grant temporary and final injunctions on such terms as it may deem reasonable to prevent or restrain infringement of a copyright.") (emphasis added). In addition, the United States is immune from injunctive relief, see 28 U.S.C. $\$ 1498$ (2000), and a number of specific uses are subject to a compulsory license, see David Nimmer, Codifying Copyright Comprehensibly, 51 UCLA L. REV. 1233, 1353-54 (2004). 
finding of infringement. ${ }^{70}$ But merely taking the Court up on its repeated suggestion won't necessarily permit the uses the courts refuse to enjoin. Copyright law has a number of other remedial doctrines designed in whole or in part to deter, rather than just to compensate for, infringement. Most notably, willful infringement is a crime either if it is done for purposes of financial gain or if it has any significant economic effect on the copyright owner. ${ }^{71}$ A court's refusal to enjoin a use will be cold comfort to a defendant who goes to jail for making the transformative but ultimately unfair use. It may be unlikely that an arguably fair use will be prosecuted criminally, but an accused infringer will be forgiven for not wanting to rely on prosecutorial forbearance.

Even beyond criminal sanctions, the copyright owner has a panoply of remedies available that far exceed likely licensing revenue. Copyright owners are entitled to an award of damages that is the greater of their losses or the defendant's gains. ${ }^{72}$ While the copyright owner's loss in a licensing-market case is presumably limited to the licensing revenue they would have been paid, the infringer's profits attributable to the infringement may well be greater. Alternatively, the copyright owner can choose at any time-even after a jury's calculation of damages ${ }^{73}$ - to elect statutory damages that can range from $\$ 200$ to $\$ 150,000$ per work infringed, depending on the defendant's intent. ${ }^{74}$ Copyright owners can also recover their attorneys' fees from the defendant in many cases, ${ }^{75}$ though close fair use cases may not be strong candidates for fee shifting.

Particularly when the defendant's use combines pieces of many different copyrighted works, statutory damages can far exceed either the copyright owner's loss or the defendant's gain. As an extreme example, consider Google Book Search, which makes intermediate copies of perhaps 2 million out-of-print copyrighted works in order to enable Internet users to find those books by searching text and viewing 4-line excerpts of each book. Because the books are out of print, the publishers do not provide any similar service, and Google does

70. See Dun v. Lumbermen's Credit Ass'n, 209 U.S. 20, 24 (1908) ("[W]e think the discretion of the court was wisely exercised in refusing an injunction and remitting the appellants to a court of law to recover such damage as they might there prove ...."); New York Times Co. v. Tasini, 533 U.S. 483, 505 (2001) ("[I]t hardly follows from today's decision [finding infringement] that an injunction ... must issue.”); Campbell v. Acuff-Rose Music, Inc., 510 U.S. 569, 578 n.10 (1994) ("[C]ourts may also wish to bear in mind that the goals of the copyright law ... are not always best served by automatically granting injunctive relief."). See also Abend v. MCA, Inc., 863 F.2d 1465, 1479 (9th Cir. 1988) (denying injunctive relief after a finding of copyright infringement), aff'd, 495 U.S. 207, 236 (1990) (leaving undisturbed the appellate court's remedial analysis). Further, the Supreme Court interpreted a similarly worded patent statute to require consideration of traditional equitable principles in every case. eBay, Inc. v. MercExchange LLC, 126 S. Ct. 1837 (2006).

71. 17 U.S.C. $\$ 506(a)$.

72. Id. $\S 504(\mathrm{~b})$.

73. Id. § 504(c)(1); Feltner v. Columbia Pictures Television, Inc., 523 U.S. 340 (1998).

74. 17 U.S.C. $\$ 504(c)(2)$.

75. Id. $\S 505$. The copyright-fee-shifting rule is even-handed, however, see Fogerty v. Fantasy, Inc., 510 U.S. 517 (1995), and attorneys' fees do represent a cost to the copyright owner, so it may not properly count in the panoply of supracompensatory remedies. 
not provide users with a copy of any significant portion of the book, there is a strong argument that the copyright owners have lost nothing at all from this use. Nonetheless, if Google loses the currently pending suits, ${ }^{76}$ under the assumptions noted above it would potentially be liable for a minimum of $\$ 1.5$ billion in statutory damages ${ }^{77}$ and a maximum of $\$ 300$ billion. Given that Google Book Search quite likely increases rather than decreases publisher revenues, and certainly does nothing close to billions of dollars' worth of damage to the copyright owners, the practical effect of such a potential damages award is to give control rather than merely compensation to the copyright owner in all but a few cases. Google may be willing to take the risk of bankruptcy to digitize books, but most companies will not be.

If copyright law is in fact to separate compensation from control in appropriate cases, it must do more than deny injunctive relief. We need a legal rule for these cases that actually provides copyright owners with compensation for their losses and nothing more. ${ }^{78}$ Without such a rule, exercising discretion to deny injunctive relief ends up being ineffective, since massively overcompensatory damages remedies can have the same practical effect as an injunction.

\section{B. Making Copyright Remedies Compensatory}

There are several ways we might change the law to compensate copyright owners without overcompensating them.

\section{Making Statutory Damages Discretionary}

The simplest possibility is to make the statutory-damages alternative discretionary with the court. One way to do this is by amending section 504(c)(1) to eliminate the words "less than $\$ 750$ or," so that copyright owners can elect statutory damages to be awarded by the jury "in a sum of not more than $\$ 30,000$ as the court considers just." ${ }^{79}$ A judge holding a bench trial who saw fit to deny injunctive relief might also exercise this new discretion to deny

76. On the American Association of Publishers lawsuit, see Association of American Publishers Sues Google over Library Digitization Plan, http://blog.searchenginewatch.com/blog/051019-115424 (last visited Sept. 24, 2006). On the Authors' Guild lawsuit, see Press Release, Authors Guild, Authors Guild Sues Google, Citing "Massive Copyright Infringement," (Sept. 20, 2005), http://www.authorsguild.org/news/sues_google_citing.htm. The publishers are apparently not asking for damages from the court, though they presumably would settle for a payment from Google that is a function of what they could collect in damages if they prevailed.

77. This assumes that the books Google is copying contain copyright notices. Since such a notice was required before 1989 and since most copyright owners use it today, this seems a reasonable assumption. If the book contained no copyright notice and Google was unaware of the claim of copyright, its damages might be reduced to $\$ 200$ per work, or a lower limit of $\$ 400$ million.

78. Because such a rule would not create an exception to copyright, but the equivalent of a compulsory license, it should be fully compliant with the Agreement on Trade-Related Aspects of Intellectual Property (TRIPs) art. 13 treaty requirement limiting exceptions to copyright, at least as long as it satisfies the treaty standards for compulsory licenses.

79. This approach would also require deleting the second sentence of section 504(c)(2), which sets a lower floor for innocent infringement. 
statutory damages in circumstances in which those damages will be supracompensatory. ${ }^{80}$ This approach could have collateral benefits in other areas, such as indirect liability. ${ }^{81}$ But since the Supreme Court has held that statutory-damage awards must be set by juries in jury trials, ${ }^{82}$ this discretion may not be exercised by the courts, and juries may be harder to persuade not to award damages when they have found liability. Judges too might decide not to exercise this discretion, ${ }^{83}$ and at the least, potential defendants may reasonably fear that factfinders won't use the discretion to avoid supracompensatory damages. Finally, this approach does not address the other ways in which copyright damages might over-deter borderline conduct.

\section{Remitting Statutory Damages in Licensing-Market Cases}

A more promising approach would expressly limit damages in a specified class of cases to the copyright owner's losses from the infringement. Doing so solves the problems with the discretionary damages approach, but it requires us to define the class of cases for which copyright-owner damages would be so

80. Courts already have the discretion to tailor statutory damages within the range, and David Nimmer has argued that courts should anchor statutory damages to some estimate of actual harm to the copyright owner, much as liquidated damages provisions in contracts are permissible only if they are designed to compensate for injury rather than to punish. NIMMER, supra note $18, \S 108.11$. But courts don't always do this, see UMG Recordings, Inc. v. MP3.com, Inc., 2000 U.S. Dist. LEXIS 13293, at *18 (S.D.N.Y. Sept. 6, 2000) (awarding \$118 million in statutory damages in a case in which the market harm was dubious), and in any event they cannot reduce the award below the minimum even if there is no market harm at all.

81. Courts apply the statutory damages rules with full force to indirect infringers. See, e.g., A\&M Records, Inc. v. General Audio Visual Cassettes, Inc., 948 F. Supp. 1449, 1458 (C.D. Cal. 1996) (applying statutory damages award to indirect infringer); Microsoft Corp. v. V3 Solutions Inc., 2003 WL 22038593 , at $* 41$ (N.D. Ill. Aug. 28, 2003) (holding direct and indirect infringers jointly and severally liable for statutory damages); Blue Ribbon Pet Prods., Inc., v. Hagen (USA) Corp. and Hagen (Canada) Corp., 66 F. Supp. 2d 454, 464 (E.D. N.Y. 1999) (same); RCA/Ariola Int'l. Inc. v. Thomas and Grayston Co., 845 F.2d 773, 777-79 (8th Cir. 1988) (same).

Statutory damages and other copyright-deterrence rules make little sense when applied to companies that are not themselves infringing copyright, but merely providing a product or service that others can misuse. This is particularly true in the digital environment, since because of an accident in the way statutory damages are calculated, anyone who is found liable for indirect infringement on the Internet faces liability of billions of dollars. If an innovator is at risk of losing her whole company (and her house and her children's education), even a very small chance of liability will be enough to deter valuable innovation. Contra Doug Lichtman, Holding Internet Service Providers Accountable, 14 SUP. CT. ECON. REV. 221 (2006) (suggesting that imposing liability on Internet service providers and other intermediaries will have beneficial effects). Although Lichtman would impose liability on Internet intermediaries to internalize the costs of the intermediary's action, under a statutory damages regime there is no way to limit such liability to the costs it imposes. Damages will radically exceed the harm an intermediary has caused in most cases.

Congress could relieve much of the pressure copyright law puts on innovation by limiting liability for indirect infringement to the actual damages caused by any such infringement. This would compensate copyright owners for their losses and force indirect infringers to bear the cost of any harm their conduct causes, but would not over-deter innovation. A discretionary rule for statutory damages would permit (but not require) judges to achieve the same result in any given case.

82. Feltner v. Columbia Pictures, 523 U.S. 340, 353 (1998).

83. Cf. John Tehranian, Whither Copyright? Transformative Use, Free Speech, and an Intermediate Liability Proposal, 2005 B.Y.U. L. REV. 1201, 1237 (2005) (noting that despite suggestions from the Supreme Court, "courts have demonstrated a remarkable reluctance to embrace a pure liability regime for copyright law"). 
limited. The class might be defined as cases in which a defendant's use is unfair only because of the copyright owner's loss of potential licensing revenue. This approach would prejudge the correctness of the American Geophysical line of decisions, however, since a Congressional response to those decisions that does not reverse them will be held as a matter of statutory interpretation to have ratified them. ${ }^{84}$ While I don't challenge those decisions in this paper, I confess that I find them troubling; I wouldn't want an effort to limit their effects to have the perverse consequence of enshrining them in the law. Particularly since the Second Circuit has recently imposed substantial limits on how far it will allow licensing markets to extend, ${ }^{85}$ Congress should do nothing to codify a contrary rule.

A preferable rule would limit damages remedies in circumstances in which the defendant had an objectively reasonable fair use defense at the time it made the use. This is a somewhat fuzzier standard, but it should include cases in which the only reason the copyright owner prevailed on the fair use defense is because of a claimed loss of licensing revenue. ${ }^{86}$ Texaco may or may not be such a case, but the transformative-use licensing-market cases will be. This may actually be a desirable limitation; the case for a liability rule is stronger when the defendant's use is transformative than when it is an exact copy. This standard may include some other failed fair use claims too, such as satires that end up taking too much of the copyrighted work for the use to be fair, but that are unlikely to do much harm to copyright-owner incentives. Unlike the discretionary approach described above, this approach would preclude the grant of statutory damages, so it wouldn't suffer from the risk that judges might choose to award supracompensatory remedies.

Interestingly, the Copyright Act already contains two very similar provisions. Section 504(c)(2) provides that "[t]he court shall remit statutory damages in any case where an infringer believed and had reasonable grounds for believing that his or her use of the copyrighted work was a fair use under

84. "Congress is presumed to be aware of [a] ... judicial interpretation of a statute and to adopt that interpretation when it re-enacts a statute without change." Lorillard v. Pons, 434 U.S. 575 (1978). The situation here is a bit different, since Congress would not be reenacting a statute without change. But when Congress acts in one way to deal with a problem and leaves another ruling intact, courts will sometimes find the intact ruling to have been ratified by Congressional action. See U.S. Postal Serv. v. Flamingo Indus., 540 U.S. 736, 745 (2004). That is what happened when Congress enacted 17 U.S.C. § 117(c) in 1998, overruling the specific result in MAI Sys. Corp. v. Peak Computing, 991 F.2d 511 (9th Cir. 1993), but leaving intact that court's problematic ruling that loading a computer program into RAM memory makes a copy.

85. See Bill Graham Archives v. Dorling Kindersley Ltd., 448 F.3d 605 (2d Cir. 2006), slip op. at 20-21; see also Castle Rock Entm't, Inc. v. Carol Publ'g Group, 150 F.3d 132, 146 n.11 (2d Cir. 1991) (questioning the application of licensing markets in derivative works cases).

86. True, there is a risk of circularity here, too. If the licensing-market model becomes so entrenched that no reasonable person could think a use fair if a licensing market exists, this standard would not apply even in licensing-market cases. But that risk does not seem particularly great. The licensing-market theory remains controversial, as the Bill Graham Archives case demonstrates. More generally, despite the alleged primacy of the fourth factor, courts periodically depart from equating fair use with the absence of market harm. See, e.g., Clean Flicks of Colo. v. Soderbergh, 2006 WL 1876624 (D. Colo. July 6, 2006); Nimmer, supra note 12, at 280. 
section $107 \ldots{ }^{87}$ But this current provision goes on to limit its reach to nonprofit institutions and public broadcasters. It could easily be broadened to cover situations in which defendants had a plausible fair use claim by deleting the rest of section 504(c)(2) after the language just quoted. Doing so will presumably reach most cases in which the plaintiff prevailed only because of a lost-licensing-revenue claim, as those cases will tend to involve reasonable fair use defenses. But the overlap is not complete, and it may be that statutory damages would not be remitted in some licensing-market cases. Further, statutory damages are not the only way in which copyright remedies are overcompensatory, and section 504(c)(2) would do nothing about those other problems.

\section{Statutory Exclusion}

The most comprehensive solution to the problem would be to draft affirmative language separately defining damages remedies in licensing-market cases. Doing so would have some advantages over the other two approaches outlined above. First, it could be tailored to reach only the set of cases of concern here. Second, it would solve not just the problem of statutory damages but also the problem of awards of defendant's profits, which are also overcompensatory when there is an established licensing market.

Here too the existing copyright statute provides a model that could be expanded. Section 104 A(d)(3)(A)(ii) ${ }^{88}$ provides that if a copyright owner has restored copyright in a previously lapsed work, it does not thereby acquire the right to prevent those who made derivative works during the period when it was legal to do so from continuing to exploit those works. Rather, such

party may continue to exploit that work for the duration of the restored copyright if the reliance party pays to the owner of the restored copyright reasonable compensation .... [T] action in United States district court, and shall reflect any harm to the actual or potential market for or value of the restored work from the reliance party's continued exploitation of the work .... ${ }^{89}$

Defining a class of derivative works for which there was a plausible claim of fair use, and subjecting them to the same reasonable compensation scheme, would go a long way toward changing the alignment of a remedies system that is heavily skewed towards deterrence (and therefore control) rather than compensation. ${ }^{90}$ But this approach has disadvantages too. It would require us to

\section{17 U.S.C. $\S 504(\mathrm{c})(2)$.}

88. 17 U.S.C. $§ 104 \mathrm{~A}(\mathrm{~d})(3)(\mathrm{A})(\mathrm{ii})$. That there is a section $104 \mathrm{~A}(\mathrm{~d})(3)(\mathrm{A})(\mathrm{ii})$ and that it has to my knowledge never been litigated lends some credence to Tony Reese's claim that the Copyright Act bears more and more resemblance to the tax code. See Lydia Pallas Loren, Digitization, Commodification, Criminalization: The Evolution of Criminal Copyright Infringement and the Importance of the Willfulness Requirement, 77 WASH. U.L.Q. 835, 885 (1999) (discussing the use of the term "tax-codification" to describe recent changes in copyright law).

89. 17 U.S.C. $§ 104 \mathrm{~A}(\mathrm{~d})(3)(\mathrm{A})(\mathrm{ii}),(\mathrm{B})$.

90. Section $104 \mathrm{~A}$ is specifically authorized by article 18 of the Berne Convention. Expanding the exception would require some other justification to be consistent with our international treaty obligations. This does not seem to pose a problem, however. The exemption in question would simply 
define a universe of cases in which there is an established licensing market, and it would lock in the American Geophysical rule.

Alternatively, Congress is currently considering creating a rule restricting the remedies available to the owners of "orphan works"-works whose author cannot be identified after a reasonable search. The version of the bill pending at this writing provides that for such orphan works, "an award for monetary relief (including actual damages, statutory damages, costs, and attorney's fees) may not be made, other than an order requiring the infringer to pay reasonable compensation for the use of the infringed work." Congress could simply piggyback licensing market cases on this "reasonable compensation" definition.

\section{Extensions and Limitations of the Compensatory Remedies Approach}

None of these approaches is perfect; each has its pros and cons. But any one of them would improve on the current system.

If this compensation experiment is successful, it could serve as a template for other issues as well. For example, Congress is currently considering limitations on copyright-owner rights for "orphan works"-works for which the copyright owner cannot easily be found. The orphan-works legislation under consideration requires some way for copyright owners to get reasonable compensation but no more. The approaches I described above could easily be adapted for orphan works as well, either by the courts (if we take the judicial discretion approach) or by Congress, which could include orphan works in the definition of cases to which the limited remedies would apply.

One possible objection to my approach contends that if copyright owners will get no more than their licensing fees in licensing-market fair use cases, defendants will have an incentive to infringe with impunity, secure in the knowledge that they will have to pay no more than they would have paid in the licensing market without litigation. There is something to this objection, but fears of rampant infringement in licensing-market cases are overblown. Bear in mind that under the discretionary and remittitur approaches, the limitation on damages and injunctive relief applies only to defendants who had an objectively reasonable good-faith defense. There is no guarantee that any defendant's defense will ultimately be deemed objectively reasonable, so there is at least some risk of injunctions or supracompensatory damages in many cases. If a fair use defense does seem ex ante to be objectively reasonable, the lack of deterrence may be a feature rather than a bug: we may want people to test the

cover cases that would have been held to be fair use before American Geophysical. Assuming the fair use defense more generally complies with Berne and TRIPs-an issue on which reasonable people can differ, see Ruth Okediji, Toward an International Fair Use Doctrine, 39 COLUM. J. TRANSNAT'L L. 75 (2000) - the proposed exemptions should, too.

91. H.R. 5439, §514(b)(1)(A), 109th Cong. (2d Sess. 2006). 
fair use line by making borderline uses. ${ }^{92}$ Further, litigation is far from costless for defendants. Defendants pay attorneys fees just as plaintiffs do and face the same disruption of their lives attending any court litigation. While my proposal will reduce copyright-owner damages in a narrow class of cases, it does so by bringing those damages into line with the copyright owner's sole injury under its own theory of the case. That doesn't seem unreasonable.

\section{$\mathrm{V}$ \\ CONCLUSION}

Copyright owners have persuaded the courts that they should win cases in which a defendant's use does not injure their market directly, but in which they could and would have charged a fee to grant permission for the use. Even assuming courts are right to have accepted this argument, it is unreasonable to then give the copyright owner not just the fee it would have charged but the power to prevent the use altogether or to collect damages far in excess of that fee. And when the defendant has produced a transformative work, giving the copyright owner that power risks suppressing creativity. Licensing-market cases are excellent choices for separating compensation and control, giving copyright owners the right to get paid without giving them control over transformative uses. Doing so is harder than simply denying injunctive relief, however. It requires a rethinking of the definition of damages in copyright law with the aim of remedying injury rather than always seeking to deter infringement.

92. Supracompensatory damages deter borderline uses because users fear that legal conduct will be misclassified as illegal. See Michael K. Block \& Joseph G. Sidak, The Cost of Antitrust Deterrence: Why Not Hang A Price Fixer Now and Then?, 68 GEO. L.J. 1131, 1132, 1138 (1980). On the problems of such "chilling effects" in copyright, see, e.g., Junelle Harris, Beyond Fair Use: Expanding Copyright Misuse to Protect Digital Speech, 11 TeX. InTELl. Prop. L.J. 83, 99 (2004); Joseph P. Liu, The DMCA and the Regulation of Scientific Research, 18 BERKELEY TECH. L.J. 501 (2003). 